\title{
KONFLIK PERILAKU KEAGAMAAN DOGMATIS DAN FUNDAMENTALIS GURU AGAMA BUDDHA
}

\author{
Warsito \\ STABN Sriwijaya Tangerang Banten \\ warsitosuranata79@gmail.com
}

\begin{abstract}
Abstrak
Dalam menyampaikan materi pelajaran guru agama Buddha perlu menggunakan pendekatan psikologis, sesuai dengan latar belakang mereka dan menjelaskan materi pokok secara mendalam, terperinci dan jelas. Kondisi dan situasi saat ini dikatakan kondisi kurang ideal dimana dalam dalam menyampaikan materi pelajaran kepada siswa berlawanan pandangannya. Guru agama Buddha harus menyesuaikan praktik dan gagasan yang sudah ada, dengan menyampaikan pelajarannya sesuai dengan karakter pendengarnya (upaya kausalya) yaitu keterampilan yang bijaksana untuk mengubah cara pandang masyarakat. Pada kenyataannya ada guru agama Buddha yang menjelaskan materi pelajaran yang diarahkan pada sekte tertentu karena pedoman yang dijadikan patokan seorang guru adalah perangkat pembelajaran yang diarahkan pada sekte tertentu pula. Hal ini berdampak pada keberlangsungan pendidikan yakni terdapat siswa yang tidak mengikuti ajaran agama Buddha dikarenakan ajaran yang ditanamkan orang tua berbeda dengan yang diajarkan di sekolah. Penanaman sikap dogmatis terus dilakukan sehingga tumbuh sikap-sikap fundamentalis terhadap ajaran agama.

Bila dalam ajaran agama dijelaskan mengenai manusia yang memilki potensi untuk berperilaku baik atau buruk. Jika potensi perilaku baik seseorang lemah, karena tidak berkembang (melalui pendidikan), maka perilaku manusia dalam hidupnya akan mengalami kemerosotan sehingga akan timbul perbuatan-perbuatan buruk seperti membunuh, mencuri, berzina, berdusta dan minum-minuman keras.

Agar perbuatan buruk dapat dikendalikan, dalam arti pemenuhannya sesuai dengan ajaran agama, maka potensi berperilaku baik itu harus dikembangkan, yaitu melalui pendidikan agama dari sejak usia dini. Apabila nilai-nilai agama telah terinternalisasi dalam diri seseorang maka dia akan mampu mengembangkan dirinya sebagai manusia bermoral, yang salah satu karakteristiknya adalah mampu mengendalikan diri dari pemuasan hawa nafsu yang tidak sesuai dengan ajaran agama.
\end{abstract}

Kata Kunci: Konflik Perilaku, Keagamaan Dogmatis dan Fundamentalis, Guru Agama Buddha 


\begin{abstract}
In conveying the subject matter the Buddhist teachers need to use a psychological approach, appropriate to their background and explain the subject matter in depth, detail and clear. Current conditions and situations are said to be less ideal conditions in which in conveying subject matter to students contrary to their views. Buddhist teachers must adapt existing practices and ideas by conveying the lessons according to the character of the listener (kausalya effort), which is a wise skill to change the outlook of society. In fact there are Buddhist teachers who explain the subject matter directed at a particular sect because the guidance that is used as a benchmark of a teacher is a learning device directed at a particular sect as well. This has an impact on the continuity of education that there are students who do not follow the teachings of Buddhism because the teachings of parents are different from those taught in school. The cultivation of dogmatic attitude continues to grow so fundamentalist attitudes toward religious teachings.

When in religious teachings explained about humans who have the potential to behave good or bad. If the potential for good behavior of a person is weak, because it does not develop (through education), then human behavior in his life will decline so that bad deeds will arise such as killing, stealing, fornication, lying and drinking.

In order for bad deeds to be controlled, in the sense of fulfillment in accordance with the teachings of religion, then the potential to behave well must be developed, ie through religious education from an early age. If religious values have been internalized in a person then he will be able to develop himself as a moral man, one of its characteristics is able to control themselves from the gratification of lust that is not in accordance with the teachings of religion.
\end{abstract}

Keywords: Behavioral Conflict, Dogmatic and Fundamentalist Religion, Teacher of Buddhist.

\title{
1. Pendahuluan
}

Pendidikan agama Buddha ditujukan untuk membentuk peserta didik menjadi manusia yang mempunyai keyakinan kepada Tuhan Yang Maha Esa, Triratna (Buddha, Dhamma dan Sangha), dan berakhlak mulia, serta peningkatan potensi spiritual. Akhlak mulia mencangkup etika, budi pekerti dan moral sebagai perwujudan dari pendidikan agama, sebagaimana yang tercantum di dalam UU Sisdiknas No. 20 tahun 2003 Pasal 3.

Peningkatan potensi spiritual mencakup pengenalan, pemahaman, dan penanaman nilai-nilai keagamaan serta penerapan nilai-nilai tersebut dalam kehidupan individu atau masyarakat. Peningkatan potensi spiritual tersebut 
pada akhirnya bertujuan pada optimalisasi berbagai potensi yang dimiliki manusia yang aktualisasinya mencerminkan harkat dan martabat manusia tersebut.

Guru agama Buddha dalam memahami ajaran agama dan menyampaikan kepada anak didik dengan standar kurikulum yang diberlakukan secara nasional. Tetapi pada kenyataannya guru agama Buddha mempunyai pandangan atau aliran yang lain sehingga tidak dapat mencapai tujuan pembelajaran sesuai dengan yang diharapkan, sebagaimana yang tercantum di dalam UU Guru dan Dosen, UU No. 14 tahun 2005 Pasal 1 ayat 1 “Guru adalah pendidik profesional dengan tugas utama mendidik, mengajar, membimbing, mengarahkan, melatih, menilai, dan mengevaluasi peserta didik pada pendidikan anak usia dini jalur pendidikan formal, pendidikan dasar, dan pendidikan menengah".

Dalam melaksanakan tugas sebagai pendidikan yang profesional yang tugas utamanya adalah mendidik, mengajar, membimbing dan mengarahkan dalam jalur formal seorang guru agama dihadapkan pada situasi yang beragam. Hal yang beragam adalah adanya siswa yang memahami ajaran agama yang berbeda. Ini disebabkan karena pengajaran dari orang tua yang mengajarkan ajaran agama yang berbeda aliran agama/doktrin agama. Perbedaan intepretasi pada doktrin agama pada suatu tingkatan tertentu akan menimbulkan adanya aliran-aliran keagamaan dan pada saat masa tertentu pula kelompok keagamaan lain akan memandang aliran-aliran keagamaan ini nampak eksklusif dan menganggap kelompoknya dikatakan paling benar dalam melaksanakan ajaran agama serta menganggap kelompok lain tidak benar. Jika ini terjadi maka potensi konflik yang akan muncul akan menghambat kerukunan antar umat beragama di Indonesia.

Konsep tentang gerakan keagamaan sebagai gerakan sosial sangat penting dalam konteks pengkajian tentang aliran-aliran keagamaan untuk melihat gerakan yang ditimbulkan melalui aliran keagamaan tersebut dipandang sebagai gerakan sosial atau gerakan yang ingin menghendaki perubahan. Setiap gerakan apapun pada dasarnya akan mengalami proses yang disebut gusfield dengan proses birokratisasi yaitu proses pembentukan struktur dalam rangka mewujudkan tujuan gerakan. Jika semakin besar suatu 
gerakan, semakin besar dan rumit struktur organisasi yang diperlukan. Konsekuensi dari struktur yang besar dan rumit adalah keharusan efisiensi organisasi, profesionalisme serta kelangsungan hidupnya yang pada gilirannya akan melemahkan sikap radikal dalam suatu agama. Bentuk gerakan ini dapat berbentuk sikap dogmatisme dan fundamentalisme yang menganggap diri sendiri lebih murni dan dengan demikian juga lebih benar daripada aliran lain. Sikap dogmatis yang membentuk kelompok fundamentalis mengajak seluruh masyarakat luas agar taat terhadap teks-teks kitab suci yang otentik dan tanpa kesalahan sehingga tumbuh dan berkembang menjadi orang yang tertutup (eksklusif) dan menutup masukan dari pendapat orang lain serta berusaha memurnikan ajaran tersebut dan mempunyai keyakinan bahwa inilah satu kebenaran. Perliaku keagamaan ini jika dibiarkan berkembang akan membahayakan dalam perkembangan pendidikan agama. Fakta yang dapat dilihat di masyarakat adalah proses pembabaran ajaran agama buddha di vihara yang hanya mengundang dharmaduta yang satu aliran dan menutup datangnya dharmaduta yang berhaluan lain.

\section{Pembahasan}

\section{a. Pengertian Potensi Konflik}

Potensi adalah kemampuan yang mempunyai kemungkinan untuk dikembangkan; kekuatan; kesanggupan; daya; (Kamus Besar Bahasa Indonesia, 890 : 2007). Konflik adalah 1) percekcokkan, perselisihan, pertentangan, 2) pertentangan antara dua tokoh (Kamus Besar Bahasa Indonesia, 587: 2007). Sedangkan menurut Wirawan (2009:5) konflik adalah proses pertentangan yang diekspresikan diantara dua pihak atau lebih yang saling tergantung mengenai objek konflik, menggunakan pola perilaku dan interaksi konflik yang mengasilkan keluaran konflik.

\section{Indikator Konflik}




\section{a. Proses}

Konflik terjadi melalui suatu proses yang unik, artinya proses terjadinya konflik berbeda dengan yang lainnya. Misalnya di Partai Demokrasi Indonesia (PDI) sampai salah satu pihak mendirikan Parta Demokrasi Indonesia Perjuangan (PDIP).

\section{b. Dua pihak atau lebih}

Konflik terjadi diantara dua pihak atau lebih. Pihak yang terlibat konflik adalah 1) antara seorang individu dan individu lainnya, 2) antara seorang individu dan satu kelompok individu, 3) antara kelompok individu dengan kelompok individu lainnya, 4) antara suatu organisasi dengan organisasi lainnya.

\section{c. Saling tergantung}

Pihak yang terlibat konflik saling tergantung satu sama lain, artinya pihak-pihak tersebut tidak bebas untuk melakukan sesuatu tanpa campur tangan atau bantuan, izin, dan merugikan atau mengurangi kebebasan pihak lainnya.

\section{d. Pertentangan mengenai objek konflik}

Objek konflik adalah sesuatu yang menyebabkan terjadinya konflik. Pihak yang terlibat konflik mempunyai perbedaan pendapat yaitu sikap atau kepercayaan mengenai objek konflik.

\section{e. Diekspresikan}

Pertentangan akan menjadi konflik jika diekspresikan. Jika pertentangan tidak atau belum diekspresikan, maka konflik bersifat laten atau tidak kelihatan. Perbedaan pendapat mengenai objek konflik sudah terjadi, tetapi kedua belah pihak diam saja dan belum terjadi interaksi mengenai perbedaan tentang objek konflik. Konflik baru terjadi ketika perbedaan tersebut dinteraksikan. Ekpresi mengenai objek konflik merupakan kejadian pemicu terjadinya konflik.

\section{f. Pola Perilaku}


Saat konflik terjadi, pihak yang terlibat menggunakan pola perilaku tertentu. Pola perilaku adalah kecenderungan orang untuk berperilaku secara tertentu dalam menghadapi situasi konflik.

\section{g. Interaksi konflik}

Proses konflik menimbulkan interaksi konflik diantara pihakpihak yang terlibat dalam konflik. Interaksi bisa berupa saling menuduh, saling menyalahkan, saling mengumpat, mencari teman, menyelamatkan muka, melakukan negoisasi atau meminta bantuan pihak ketiga untuk menyelesaikan konflik.

\section{h. Keluaran Konflik}

Interaksi konflik diantara pihak-pihak yang terlibat dalam konflik menghasilkan keluaran konflik yang unik, untuk masing-masing konflik. Keluaran konflik bisa berupa ditemukannya solusi atas suatu konflik.

Konflik merupakan salah satu esensi dari kehidupan dan perkembangan manusia yang mempunyai karakteristik beragam. Manusia memiliki perbedaan jenis kelamin, strata sosial dan ekonomi, sistem hukum, bangsa, suku, agama, kepercayaan, aliran politik, serta budaya dan tujuan hidupnya. Dalam sejarah umat manusia, perbedaan inilah yang selalu menimbulkan konflik. Selama masih ada perbedaan tersebut, konflik tidak dapat dihindari dan selalu akan terjadi.

\section{Paham Dogmatisme}

\section{a. Pandangan Dogmatis secara umum}

Dogma adalah pokok ajaran atau kepercayaan yang harus diterima sebagai hal yang benar dan baik, tidak boleh dibantah dan diragukan (Kamus Besar Bahasa Indonesia : 272). Dogmatisme adalah doktrin bahwa pikiran manusia mampu untuk mengetahui dengan kebenaran. Dogmatisme sebagai suatu sistem kepercayaan yang dapat membuat orang menjadi ekstrim. 


\section{b. Pandangan agama Buddha tentang Dogmatis}

Setiap agama mempunyai ajaran atau doktrin yang berbeda-beda. Ada beberapa agama yang sangat percaya dengan dogma. Agama Buddha mempunyai pandangan yang berbeda terhadap dogma. Oleh karena itu pada kesempatan ini penulis akan membahas dogmatisme serta bagaimana pandangan agama Buddha itu sendiri terhadap dogmatisme.

Agama Buddha memiliki pandangan yang agak berbeda dengan yang terdapat pada agama-agama lain mengenai dogma. Alasan yang mendasar Agama Buddha agak berbeda dengan agama-agama lain ialah karena Agama Buddha tidak begitu menggaris bawahi kepercayaan mengenai sesuatu apabila yang dipercayai itu merupakan sesuatu yang tidak bisa dinalar oleh akal manusia serta menolak dogmatisme. Dalam agama Buddha dogma cenderung mengarah pada hal yang negatif mempercayai dogma dalam agama Buddha termasuk dalam pandangan yang salah. Dalam Brahmajala Sutta terdapat 62 pandang salah salah satunya adalah percaya pada dogma.

Berkaitan dengan dogma dalam Kalama Sutta dijelaskan mengenai doktrin jangan percaya begitu saja dengan suatu ajaran yang secara turun temurun karena dikatakan oleh orang yang lebih tua, jangan percaya terhadap kitab suci, jangan percaya terhadap pembicaraan yang kelihatannya menyakinkan atau bahkan pada pertapa sebelum kalian benar-benar mengetahui sendiri.

Berdasarkan sutta ini sudah sangat jelas segala sesuatu harus disaring dan disikapi dengan bijaksana jangan menelan mentah-mentah apa yang sudah kita dengar hanya karena orang yang menyampaikan itu lebih tua dari kita. Berdasarkan hal di atas dapat disimpulkan bahwa dogma merupakan paham yang harus dipatuhi dan tidak dapat ditolak. Pandangan agama Buddha sendiri menolak dogmatisme karena dogmatisme dapat mengarah ke hal yang negatif orang yang percaya dengan doktrin sebuah ajaran akan mempunyai pandangan yang salah. Dalam menyikapinya doktrin sebuah ajaran adalah dengan bijaksana jangan menelan doktrin tersebut mentahmentah. 


\section{Paham Fundamentalis}

Sebuah gerakan dalam sebuah aliran, paham atau agama yang berupaya untuk kembali kepada apa yang diyakini sebagai dasar-dasar atau asas-asas (fondasi). Karenanya, kelompok-kelompok yang mengikuti paham ini seringkali berbenturan dengan kelompok-kelompok lain bahkan yang ada di lingkungan agamanya sendiri. Mereka menganggap diri sendiri lebih murni dan dengan demikian juga lebih benar daripada lawan-lawan mereka yang iman atau ajaran agamanya telah "tercemar". Kelompok fundamentalis mengajak seluruh masyarakat luas agar taat terhadap teks-teks Kitab Suci yang otentik dan tanpa kesalahan. Mereka juga mencoba meraih kekuasaan politik demi mendesakkan kejayaan kembali ke tradisi mereka.

Istilah fundamentalisme cukup hangat dibicarakan di media massa, tidak hanya di tingkat nasional tapi internsional juga. Hal ini terjadi seiring merebaknya aksi terorisme yang berlindung di bawah paham fundamentalis agama terutama Islam. Sehingga istilah fundamentalis identik dengan "fundamentalisme islam" atau "islam fundamentalis" yang memiliki kesan negatif dan ekstrimisme.

Padahal kalau dilihat lebih dalam lagi fundamentalis yang berakar pada agama ini tidak hanya islam saja tapi juga agama lain (Kristen, Katolik, Hindu, Buddha, Yahudi dan Konghucu). Bahkan istilah fundamentalisme itu muncul pertama kalinya di dunia Barat oleh gerakan Kristen Protestan Amerika. Mereka memerangi masyarakat sekuler yang baik maupun yang buruk, mengisolasi dari kehidupan bermasyarakat dan memusuhi akal pikiran hasil penemuan ilmiah.

Fundamenetalisme dipersepsikan masyarakat dunia saat ini merupakan pemaknaan yang diproduksi oleh bangsa Barat. Fundamentalisme yang menunjuk pada sikap-sikap yang ekstrem, hitam putih, tidak toleran, tidak kompromi, dan segalanya yang asosiatif. Agama dijadikan mereka sebagai alat untuk melakukan intimidasi, penindasan kepada sekelompok orang yang bertentangan dengan paham mereka. Padahal agama manapun tidak mengajarkan demikian. Nilai-nilai kemanusiaan agama mereka tinggalkan. Agama yang dibangun dari integrasi akal pikiran rasional dengan non-rasional sehingga menciptakan pikiran yang masuk akal (rasional), telah 
beralih peran yang mengarah kepada penciptaan rasionalitas untuk berindak anarkis. Agama yang berfungsi memenuhi kebutuhan rohani manusia menjadi tenteram, damai, dan aman telah beralih pada kebencian, kegelisahan dan ketakutan. Agama yang memiliki prinsip nilai-nilai kemanusiaan untuk meningkatkan kulaitas kemanusiaan manusia telah berganti dengan nilai-nilai kekerasan dan fanatisme sempit.

Paham fundamentalisme agama yang demikian inilah, yang harus dibenarkan dan diluruskan. Paham fundamentalisme agama ini tidaklah harus dihapus keberadaannya. Paham fundamentalisme itu diperlukan dalam kehidupan beragama, untuk menunjukkan eksistensi keyakinan manusia, sehingga agama dapat menyebar sampai saat ini tidak lain adalah peran para fundamentalis agama untuk mengajarkan arti eksistensi manusia hidup di dunia sesuai norma-norma moralitas kemanusiaan manusia. Akan tetapi melencengnya para fundamentalis agama dari koridor-koridor aturan agama ini, telah mengakibatkan berkembangnya paham fundamentalisme baru yang berpandangan sempit.

Paham inilah yang berbahaya dan harus dibenarkan dan diluruskan untuk kembali kepada koridor-koridor agama yang benar. Paham seperti ini sangat berbahaya tidak hanya akan menimbulkan kerusakan dan anarkis saja, akan tetapi yang lebih berbahaya akan merusak fungsi dan peran agama itu sendiri. Nilai moralitas yang timbul dari agama akan semakin ditinggalkan para pengikutnya. Untuk melawan fundamentalisme agama yang berpikiran sempit ini, perlu diperlukan proses pelurusan dan pendidikan sesuai dengan ajaran agama masing-masing. Proses pelurusan ini dilakukan dengan meluruskan persepsi manusia akan agama untuk kembali kepada koridor yang benar. Kesalahan perspesi ini telah menimbulkan paham-paham fundamentalisme yang akan merusak nilai universalitas agama itu sendiri. Pelurusan ini sebagai langkah untuk mengembalikan posisi paham fundamentalisme agama ke jalan yang benar. Posisi fundamentalisme agama yang mampu mengantarkan kebersamaan dan berdampingan hidup dalam sebuah perbedaan. Posisi yang tetap memberi kebebasan untuk menyebarluaskan ajaran agama dengan tetap memperhatikan persaudaraan, kerukunan dengan penganut agama lainnya. 


\section{Guru agama Buddha}

Semakin maju suatu masyarakat, semakin dirasakan pentingnya sekolah dan pendidikan secara teratur bagi pertumbuhan dan pembinaan anak dan generasi muda pada umumnya. Pada masyarakat yang sangat sederhana, seperti mereka yang hidup di hutan, di pulau terpencil, atau di tempat yang belum mengenal kemajuan sama sekali, memang sekolah tidak diperlukan oleh orangtua, karena mereka secara tidak sengaja akan melatih anak-anaknya dari kecil mengikuti jalan hidupnya, keyakinan agamanya dan keterampilan sederhana yang dimilikinya, misalnya ke sawah, ladang, mencari kayu atau menangkap ikan. Adat istiadat, sopan santun yang berlaku dalam lingkungan, dipelajari oleh anak secara alamiah, dengan meniru, mencoba atau melatih diri tanpa tuntunan yang pasti.

Kehidupan dan pertumbuhan peserta didik yang seperti itu tidak dapat dipertahankan lagi, karena kemajuan ilmu pengetahuan dan teknologi telah berkembang sebegitu jauh, sehingga kepandaian dan keterampilan tidak mungkin lagi berpindah dari generasi tua kepada generasi muda melalui pengalaman hidup dengan orangtua saja, akan tetapi oleh orang yang mempunyai kemampuan dan keterampilan untuk itu, yaitu guru. Semakin tinggi tingkat sekolah, semakin banyak bidang ilmu dan keterampilan yang harus dimiliki oleh guru, sehingga seorang guru tidak akan mampu menguasai segala macam ilmu dan kepandaian, maka perlu ada keahlian dan orang-orang yang mendalami masing-masing ilmu tersebut. Salah satu bidang ilmu pengetahuan yang didapatkan sejak tingkat sekolah dasar hingga menengah atas ialah Pendidikan Agama. Di dalamnya terdapat cabang, seperti Pendidikan Agama Budha, di mana bidang-bidang Pendidikan Agama tersebut diajarkan dengan bergantung kepada agama yang dipeluk oleh sang peserta didik. Bila peserta didik beragama Buddha maka ia akan mendapatkan materi pelajaran Pendidikan Agama Buddha. Seluruh mata pelajaran di atas tentunya memerlukan guru sebagai pihak yang berwenang memberikan pelajaran. Indonesia dikenal sebagai sebuah negara yang terdiri dari beragam suku, agama dan bahasanya menyebabkan hubungan dan interaksi dari hal yang berbeda menimbulkan potensi 
konflik. Dalam perbedaan agama yang ada, di dalamnya ada aliran dalam suatu agama yang mengandung potensi permusuhan intern dalam umat beragama dan ekstern antar umat beragama.

Pluralitas agama menyimpan potensi sekaligus bahaya tersendiri. Kemajemukan agama itu bisa menjadi potensi kuat, apabila kemajemukan tersebut dihargai dan diterima oleh masyarakat yang ada. Disisi lain, kemajemukan menyimpan potensi untuk menimbulkan masalah yang besar. Perbedaan-perbedaan ajaran agama apabila tidak ditanggapi dengan bijaksana, maka dapat memicu sebuah pertikaian yang meluas. Setelah era reformasi ternyata banyak konflik berdarah diberbagai daerah di Indonesia. Kebanyakan dari konflik tersebut mempunyai nuansa agama yang sangat kental. Seperti biasanya, pemerintah dan elit politik cenderung mengatakan bahwa konflik-konflik tersebut bukan konflik agama, tetapi agama hanya dijadikan alat penggalangan massa. Penyebab konflik tersebut adalah kesenjangan ekonomi ataupun pertarungan politik tingkat atas dan agama hanya sebagai label yang diikutsertakan untuk mendapatkan dukungan.

\section{Bentuk-Bentuk Konflik}

Konflik dalam masyarakat dapat digolongkan ke dalam beberapa bentuk konflik yakni :

\section{a. Berdasarkan sifatnya}

Berdasarkan sifatnya, konflik dapat dibedakan menjadi konflik destruktuif dan konflik konstruktif. Konflik Destruktif merupakan konflik yang muncul karena adanya perasaan tidak senang, rasa benci dan dendam dari seseorang ataupun kelompok terhadap pihak lain. Pada konflik ini terjadi bentrokan-bentrokan fisik yang mengakibatkan hilangnya nyawa dan harta benda seperti konflik Poso, Ambon, Kupang, Sambas, dan lain sebagainya. Konflik Konstruktif merupakan konflik yang bersifat fungsional, konflik ini 
muncul karena adanya perbedaan pendapat dari kelompok-kelompok dalam menghadapi suatu permasalahan. Konflik ini akan menghasilkan suatu konsensus dari berbagai pendapat tersebut dan menghasilkan suatu perbaikan. Misalnya perbedaan pendapat dalam sebuah organisasi.

\section{b. Berdasarkan Sifat Pelaku yang Berkonflik}

1. Konflik Terbuka, merupakan konflik yang diketahui oleh semua pihak. Contohnya konflik Palestina dengan Israel.

2. Konflik Tertutup, merupakan konflik yang hanya diketahui oleh orangorang atau kelompok yang terlibat konflik.

\section{Konflik dalam Pendidikan agama}

Jika memperhatikan konflik-konflik yang terjadi di Indonesia akan terlihat jelas bahwa unsur-unsur agama yang menjadi pemicu dan pelestari konflik. Hal ini dapat dilihat dari konflik maluku yang masih berkepanjangan, masalah agama yang terkait dengan konflik tersebut yang menyebabkan masalah tersebut sulit untuk diselesaikan.

Negara Indonesia bukanlah negara sekuler dan juga bukan negara agama. Negara Indonesia adalah negara yang berketuhanan yang maha esa, agama mendapatkan tempat perhatian yang cukup besar. Kementerian agama adalah lembaga agama yang mengurusi masalah kerukunan intern dan kerukunan eksteren umat beragama. Bentuk perhatian pemerintah terhadap agama adalah dengan adanya kewajiban mengikuti pelajaran agama dari jenjang Sekolah Dasar (SD) sampai Perguruan tinggi. Dari sini terlihat jelas bahwa pentingnya suatu agama untuk dianut bagi setiap penduduk intern umat beragama dan ektern antar umat beragama. Yang dihasilkan dalam pendidikan agama tidak memenuhi harapan, jika melihat konflik-konflik yang pernah terjadi bernuansa agama yang kental. Pendidikan agama sepertinya telah gagal untuk menghasilkan orang-orang yang mempunyai integritas dan kesdisiplinan yang tinggi dalam beragama. Ini terbukti dengan marakya kasus-kasus korupsi, kolusi dan 
nepotisme yang tak kunjung renda sehingga agama lama-kelamaan akan menjadi terpecah.

\section{a. Pandangan dogmatis}

Dogmatis adalah pandangan yang bersifat mengikuti atau menjabarkan suatu ajaran tanpa kritik sama sekali sedangkan dogmatik adalah ihwal ajaran serta keyakinan agama atau kepercayaan yang tidak boleh dipersoalkan (Kamus Besar Bahasa Indonesia, 272: 2007).

Berkaitan dengan pandangan di atas dapat dijelaskan dalam masalah di masyarakat umum, ada pandangan bahwa bidang studi agama adalah bidang studi yang dapat dikatakan ecek-ecek atau mudah, murah dan tidak penting. Rendahnya tingkat penghargaan khususnya dalam bentuk finansial telah menjadi mata rantai yang sulit terputuskan dalam meningkatkan kualitas tenaga pendidik.

Dalam wacana diskusi mengenai pluralitas agama pendidik seolah-olah tertinggal, ditinggalkan bahkan dapat dianggap tidak ada. Karena dalam wacana diskusi biasanya diikuti oleh pemikir, aktivis lembaga-lembaga keagamaan yang sangat jarang melibatkan guru agama. Guru agama sebenarnya sangat potensial dalam memberikan wawasan pluralitas agama ke tingkat bawah. Jika guru agama tida meningkatkan pengetahuan secara terus menerus maka ia akan tertinggal dari perkembangan nyata di masyarakat. Berkenanaan dengan metode selama ini, tampaknya metode pendidikan agama di Indonesia lebih menekankan pada tercapainya kemampuan kognitif dalam pengetahuan agama. Pendidikan agama menjadi sekedar penyampaian informasi kebenaran-kebenaran agama yang harus dipahami oleh murid. Kebenaran-kebenaran ini bahkan hanya ditampilkan sebagai sesuatu yang harus diterima dengan begitu saja, pantang untuk dipertanyakan kebenarannya. 


\section{b. Pandangan fundamentalis}

Pandangan Fundamentalis dapat dijelaskan sebagai berikut:

Fundamentalis adalah penganut gerakan keagamaan yang secara kolot dan reaksioner yang selalu merasa perlu kembali ke ajaran agama yang asli seperti yang tersurat dalam kitab suci, sedangkan fundamentalisme adalah paham yang cenderung untuk memperjuangkan sesuatu yang radikal (Kamus Besar bahasa Indonesia, 322: 2007)

Melihat doktrin ajaran yang sangat mendasar maka setiap agama yang bersifat fundamentalis dituntut kembali keajaran asli dari suatu ajaran agamanya.

\section{Konflik Agama}

Konflik agama bisa terjadi di antara dua pemeluk agama yang berbeda atau diantara para pemeluk agama yang sama. Konflik agama adalah konflik diantara pemeluk, bukan konflik diantara ajaran atau kitab suci agama. Dari segi ajaran dan kitab suci agama, memang ada perbedaan mengenai ajaran atau doktrin agama. Perbedaan diantara ajaran agama merupakan objek dari ilmu perbandingan agama. Akan tetapi, pihak yang terlibat konflik bukan kitab suci, doktrin atau ajaran agamanya melainkan para penganut agamanya atau umatnya.

Konflik agama banyak jenisnya, seperti :

1. Konflik para penganut suatu agama

Konflik atau perbedaan pendapat bisa terjadi diantara para penganut suatu agama. Sumber dari konflik adalah penafsiran yang berbeda mengenai penafsiran kitab suci atau ajaran agama oleh para pemimpin agamanya. Dari sini lahir sekte atau mazhab/aliran dalam suatu agama tertentu. 
2. Konflik antara agama dan ilmu pengetahuan serta budaya Konflik ini pernah terjadi pada abad pertengahan. Contohnya konflik antara paus dengan ilmuwan Galileo Galilei, pengikut Copernicus mengenai rotasi bumi dan matahari.

3. Konflik diantara para penganut agama yang berbeda Konflik diantara para penganut agama sering menimbulkan konflik fisik dan kekerasan. Pada abad pertengahan pernah terjadi konflik antara penganut agama Islam dengan penganut agama Kristen yang menimbulkan perang salib.

4. Konflik karena pemanfaatan agama untuk tujuan tertentu.

Konflik ini dijadikan alat untuk mencapai tujuan politik, ekonomi dan sosial dari suatu individu atau kelompok tertentu. Dalam bidang politik, agama digunakan sebagai ideologi dan simbol partai politik untuk mencapai kekuasaan politik.

\section{Penutup}

Konflik agama dapat terjadi dan meluas menjadi banyak sekte dalam agama bahkan lebih parah lagi menjadi pecahan sekte. Seperti dalam agama Buddha ada sekte mahayana terdapat sekte yang ada di dalamnya yakni sekte tanah suci, sekte nichiren shosu Indonesia dan lain-lain. Jika semua perbedaan tersebut hanya untuk konsumsi para penganut agama sendiri, kemungkinan terjadi konflik kecil. Namun jika ada pemaksaan dalam ceramah kepada penganut agama lain dan menganggap satu-satunya yang paling benar maka akan memicu timbulnya suatu konflik. Dalam materi pendidikan agama dapat dikategorikan menjadi dua bagian yakni 1) ajaran (doktrin) dan praktik agama. Titik berat pembelajaran di kelas diarahkan pada masaah ajaran, dengan memberikan penekanan yang kurang terhadap masalah praktik agama. Ajaran sangat penting untuk diajarkan dalam 
pembelajaran agama, tetapi tanpa praktik maka pembelajaran tersebut akan sia-sia.

\section{DAFTAR PUSTAKA}

Baghi, Felix (2012) Pluralisme, Demokrasi dan Toleransi. Moya Zam Zam Printika

Effendi, Johan (2010). Pluralisme \& Kebebasan Beragama, Yogyakarta: Institut Dian.

Kamus Besar Bahasa Indonesia. (2005). Jakarta: Balai Pustaka.

Naim, Ngainun \& Sauqi, Achmad (2008). Pendidikan Multikultural Konsep dan Aplikasinya

Nasution. (1996). Metode Penelitian Naturalistik Kualitatif. Bandung: Tarsito.

Qodir, Zuly (2011). Sosiologi Agama, Pustaka Pelajar. Yogyakarta.

S.Coleman, James (2008). Dasar-dasar Teori Sosial, Bandung: Nusa Media.

Sugiyono. (2008). Metode Penelitian Kuantitatif Kualitatif dan R E D. Bandung: Alfabeta.

Syafi'i Mufid, Ahmad (2009). Kasus-kasus Aliran/Paham Keagamaan aktual di Indonesia, Jakarta: Puslitbang Kehidupan Keagamaan.

Wirawan (2010). Konflik dan Manajemen Konflik Teori dan, Aplikasi, dan Penelitian, Jakarta: Salemba Humanika.

\section{Peraturan}

Undang-Undang Nomor 20 tahun 2003 tentang Sistem Pendidikan Nasional Undang-Undang Nomor 14 tahun 2005 tentang Guru dan Dosen 